\title{
Johannes Oecolampadius.
}

An Exposition of Genesis. Trans. and intro. Mickey L. Mattox.

Milwaukee, WI: Marquette University Press, 2013. Pp. 207. ISBN 978-0-87462713-8 (paperback) \$20.

Johannes Oecolampadius (1482-1531) was one of the great humanist scholars of the sixteenth century and the lead reformer in Basel before his death at age 49. He assisted Erasmus with the preparation of the Novum Instrumentum in 1516. A few years later, he translated the sermons of John Chrysostom from Greek into Latin - a text that became so popular even Roman Catholic printing presses used it, after removing the translator's name to avoid the embarrassment of publishing the work of a "heretic." It was, however, the Bible that occupied Oecolampadius's time, in his role as leading preacher and teacher of the Reformation in Basel. In 1529, the city council adopted the Reformation and specified that each day, at 3 o'clock pm, the public should be provided with biblical instruction. Oecolampadius's in Genesim Enarratio (Basel: Bebel, 1536) originated from these afternoon lectures. When Oecolampadius died, he had made it through only sixteen of the 50 chapters of Genesis. Mickey Mattox has provided us with a translation of the first three.

Genesis interested people in the early modern era just as much as it does people today, so it is not surprising that Oecolampadius made it the basis of his public lectures; the Gospel of Matthew was used as the New Testament book. Following his death, Oecolampadius's lecture notes were compiled, edited, and published in octavo format-intended to be affordable and, probably, for use by pastors, a fact that doubtless would have pleased its author. Mattox has given 
us the Latin text (verso) faced by his own English translation, which he based on the Herzog August Library's copy of the book. I could not find a copy of the original online, so am grateful for the decision to provide both texts. The translation is less stilted than Mattox thinks. He explains in the introduction that he adopted a word-for-word rather than sense-for-sense approach to translation; and while it is more accurate, he claims it is less elegant. However, I found the translation to be fluid and certainly readable.

Oecolampadius, too, emerges from the pages of this book as a man concerned with explaining the clear meaning of the text-what most reformers would have called the literal sense. He was not opposed, however, to using the allegorical or anagogical sense when the plain reading offered little to edify. It is, of course, not surprising that Oecolampadius was thoroughly Christian, finding the Trinity in chapter 1 , for example. He is, however, far more conversant with the early Church Fathers than most of his contemporaries-and here his work on Chrysostom bears fruit.

Not many early modern commentaries have been translated-the notable exceptions being by "giants" such as Luther and Calvin. What Mattox provides for us here is a glimpse of what lies beyond their shadow. Commentaries help round out our understanding of the place of the Bible in the sixteenth century; for while Oecolampadius is indebted to both Luther and Zwingli, this commentary does not mirror either one exactly. Instead, what comes across is Oecolampadius's own voice; a voice worth hearing. Professor Mattox is to be thanked for providing this translation.

DAVID M. WHITFORD

Baylor University 